\title{
Intersectoral actions between health and education: notes on the Health at School Program
}

\author{
I ${ }^{1}$ Myriam Dantas Pereira, 2 Ilana Moutian, ${ }^{3}$ Rafaela das Graças Santiago Faria, \\ ${ }^{4}$ Darilene Rocha Cordeiro, ${ }^{5}$ Selma Maria da Fonseca Viegas I
}

Abstract: Objective: to understand the intersectoral actions between health and education and the Health at School Program context in three municipalities in different health regions in the state of Minas Gerais, Brazil. Method: this is a holistic-qualitative multiple case study, based on Comprehensive Sociology of Everyday Life, with 91 participants, being 38 health professionals and 53 education professionals. Open-ended individual interview and records in operational field notes of the research development were used. Data were collected in 2016 and thematic content analysis was used, obeying the analytical technique of crosscase analysis, in line with the methodological framework of the holistic multiple case study. Results: low involvement between the health and education sectors is pointed out, leading to the practice of fragmented, punctual and limited actions and implying low improvement in health conditions. Conclusions: to modify this context, the involvement of health and education professionals is essential, in addition to the schoolchildren, parents, community and managers themselves. The union of these actors is necessary for the transformation of students' health conditions. However, this will only be achieved if the actions developed are planned and carried out involving these actors and the school community.

> Keywords: intersectoral collaboration; health; education; school health; health promotion.

\author{
1 Universidade Federal de São João \\ Del Rei. Divinópolis-MG, Brasil \\ (myriamdantas2014@gmail.com) \\ ORCID: 0000-0002-7775-1027 \\ ${ }^{2}$ Universidade Federal de São \\ João Del Rei. Divinópolis-MG, \\ Brasil (paulalgpereira@gmail.com). \\ ORCID: 0000-0002-0565-1879 \\ ${ }^{3}$ Universidade Federal de São João \\ Del Rei. Divinópolis-MG, Brasil \\ (rafaelafaria01@hotmail.com). \\ ORCID: 0000-0001-9508-8372 \\ ${ }^{4}$ Universidade Federal de São \\ João Del Rei. Divinópolis-MG, \\ Brasil (darilenerc@yahoo.com.br) \\ ORCID: 0000-0002-8982-9143 \\ ${ }^{5}$ Universidade Federal de São \\ João Del Rei. Divinópolis-MG, \\ Brasil (selmaviegas@ufsj.edu.br). \\ ORCID: 0000-0002-0287-4997
}

Recebido em: 24/06/2019 Aprovado em: 07/03/2020 Revisado em: 18/05/2021 


\section{Introduction}

Centralized, vertical, fragmented and divided public interventions by sector are no longer sufficient to solve the population's health requirements. To meet health demands, the establishment of bonds, an exchange of knowledge, potential and experiences between the actors and the public services involved is considered, defragmenting the actions and services with the aim of promoting and enhancing cooperative, resolving and articulated networks (DIAS; VIEIRA; SILVA et al., 2016). Intersectoriality needs to happen in an articulated way and integrate public policies for more significant effects on the population's quality of life. From this perspective, intersectoral action allows the subject to be fully served, guaranteeing the right to health and life with more quality (VIEGAS; PENNA, 2015).

As an intersectoral strategy, the Health at School Program (PSE - Programa Saúde na Escola) was established by Decree 6,286 of December 5, 2007, which integrates actions by the Ministry of Health and the Ministry of Education with the execution of simultaneous work to obtain impactful results on the determinants of health-disease and the promotion of better quality of life. This program provides students in the public school system with greater access to health interventions through health promotion activities, prevention of risks and injuries, coping with social vulnerabilities and problems associated with the learning process (BRASIL, 2007; BRASIL, 2009).

The school plays an important role in promoting and protecting students' health (GONDIM; SOUTO; MOREIRA et al., 2015). Its space allows students, parents, teachers and employees to meet, allowing the operationalization of PSE. This program aims to expand health actions, aimed at students, from the difficulties listed in the school routine, articulating health and education, developing actions to prevent risks and injuries, health promotion, and care. Comprehensiveness, territoriality and intersectoriality are principles that underlie the Program (SOUSA; ESPERIDIÃO; MEDINA, 2017). Through health education work, it is possible to enable the adoption of healthy life behaviors allowing an adequate development, in addition to the significant reduction of diseases (LÓPEZ; FIERRO; MONTOYA et al., 2016).

Health and education are an instrument capable of providing empowerment and social transformation. For this, a collective effort between sectors is necessary in 
order to develop comprehensive and integrated practices (RIBEIRO; RIBEIRO, 2015). Empowering involves the human condition and what the human being has to teach us, "urging us to change our gaze and direction, teaching us that instead of trying to standardize people, it is necessary to encourage each human being, involving their power" (NITSCHKE et al., 2017, p. 10).

Although its advantages and uses are recognized, intersectoral work is not always effective or easily achieved, due to the different agendas of priorities in the health and education sectors or even due to the lack of information from teachers on health issues, many without necessary training for the development of educational actions due to the complexity of students' demands (MONTEIRO; BIZZO, 2015). The lack of resources and trained professionals ends up influencing the actions developed in the school universe, which highlights the need for interdisciplinary work and intersectoral collaboration (SOARES; LEITE, 2015).

The lack of articulation of actions between health and education professionals can impair the monitoring of students, in addition to affecting the performance of PSE activities, as intersectorality is an important pillar for this program (BRASIL; SILVA; SILVA; RODRIGUES et al., 2017). Planning and carrying out PSE actions must be done in an intersectoral way, in order to achieve a more just and healthy reality, with the creation of spaces where students, teachers, health professionals and the community participate (CHIARI; FERREIRA; AKERMAN et al., 2018).

In this context, the question is: how are intersectoral actions developed between health and education and what is the context of PSE in municipalities of Minas Gerais? What is the participation of Primary Health Care professionals and public and district schools in PSE actions? Do the actions developed in PSE indicate intersectorality?

This study aimed to understand the intersectoral actions between health and education and the Health at School Program context in three municipalities in different health regions in the state of Minas Gerais, Brazil.

\section{Methods}

This is a holistic-qualitative multiple case study (YIN, 2015), based on the Comprehensive Sociology of Everyday Life theoretical framework (MAFFESOLI, 2010). 
The case study method, in the qualitative approach, allows the researcher to study the phenomenon (the case) covering the entire context in which it is inserted and deeply understanding how the individual experiences each situation. By combining several single case studies, carried out separately completely in the same research, it becomes known as a multiple case study. The study of multiple cases is considered more robust, as it increases the ability to generalize the results, since it increases the chances of finding similar results due to data saturation in the various cases, following the logic of literal replication (YIN, 2015). This multiple case study is holistic in that it presents a single unit of analysis (YIN, 2015): the context of integration between health and education and (non) adherence to PSE.

Comprehensive Sociology of Everyday Life proposes the use of sensible reason in order to offer another view on human relations. It enabled analysis and understanding of intersectoral actions in education and health professionals' daily lives from three different realities, involving different views and the context of intersectoral work with or without adherence to PSE. For this analysis, it was necessary to have a balance between reason and feeling, since a single event is open to several explanations in different realities that bring similar results. Living is heterogeneous and plural, requiring a broad and comprehensive understanding that, in this study, encompasses intersectoral actions for on-site care and health promotion in students' lives. For that, it is necessary to be attentive to simple and small things (MAFFESOLI, 2010), "to the way of life of human beings that shows itself in daily life, expressed by their interactions, beliefs, values, symbols, meanings, images and imagery, thus outlining their process of living, in a movement to be healthy and get sick, punctuating their life cycle" (NITSCHKE et al., 2017, p. 8).

The study was carried out in three municipalities in Minas Gerais, Brazil: Curvelo, Itapecerica and Sete Lagoas, belonging to different health regions. The scenarios are composed of municipalities classified considering the quantitative population parameter: small ( $<50$ thousand inhabitants), medium (between 50 thousand and one hundred thousand inhabitants) and large ( $>100$ thousand inhabitants).

The municipality of Curvelo is located in the central region of Minas Gerais and has an estimated population of 79,401 inhabitants (IBGS, 2016). The city has joined PSE since 2014 and the program is developed in two district schools. It has a total of 16 teams from Family Health Strategy (FHS), corresponding to $87.5 \%$ coverage, 14 public schools and seven district schools. The city of Itapecerica, located 
in the central-western region of Minas Gerais, during the period of data collection of this study, did not have adherence to PSE. It has an estimated population of 22,134 inhabitants (IBGS, 2016), with five FHS, corresponding to $70.3 \%$ coverage, seven public schools and six district schools. The city of Sete Lagoas, located in the metropolitan mesoregion of Belo Horizonte, has been a member of PSE since 2013, currently with $100 \%$ coverage. Its estimated population is 234,221 inhabitants (IBGS, 2016). It has 45 FHS teams, ten Primary Health Care Units (PHC), 30 public schools and 41 district schools (Field Notes (FN)).

As it is a program developed jointly between health and education, 91 professionals from both sectors participated in the study, 38 of them from health and 53 from education (of the 91, 28 are from Itapecerica; 38, from Sete Lagoas and 25, by Curvelo). Of the total number of participants, 76 (83.52\%) were female, had a mean age in health of 35.4 years and, in education, 45.6 years. The length of experience in health has an average of 7.1 years and, in education, 19.5 years. As for participants' position and role, two doctors, seven nurses, three nursing technicians, 14 community health workers, four dental surgeons, two oral health assistants, one psychologist, six directors, seven deputy directors were included, seven school supervisors, 28 teachers, three general service assistants, three district health and two education departments, two PHC and PSE coordinators. The inclusion criterion adopted was having one year or more of experience in the role/position and, by exclusion, professionals being away from work on the date of data collection.

The sources of evidence were an open-ended, intensive, individual interview, recorded and transcribed in full and records in operational field notes (FN) for research development. Field notes, as a source of evidence, are essential elements in the preparation of operational research records during fieldwork and continue until analysis (YIN, 2015).

The data were collected from June to August 2016. Data collection locations in the municipalities were determined was based on a random drawing of FHS units and of public and district schools with or without adhesion to PSE. In Curvelo there was a public school, two district schools and three FHS teams. In Itapecerica, a public school, three district schools and two FHS teams. In Sete Lagoas, two public schools, three district schools and two FHS teams (FN). The interview was conducted individually through a semi-structured script. A priori, a pretest was carried out with the interview script. The guests were approached at the 
workplace, where they were informed about the risks and objectives of the study. After voluntary consent, all signed the Informed Consent Form and only one guest denied participation in the research. The interviews were conducted in a reserved place, with the presence of only the interviewer and the interviewees, had an average duration of 12 minutes and 16 seconds and were recorded with prior authorization. To ensure confidentiality of information and participants' anonymity, alphanumeric codes were used: respondents from the education sector were identified by the letter $\mathrm{E}$, and those from the health sector were identified by the letter $\mathrm{H}$, plus the number of the interview sequentially $\left(\mathrm{E}_{-1}, \mathrm{E}_{-2}, \mathrm{H}_{-1,} \mathrm{H}_{-2}\right.$, etc).

In order to meet the criteria of qualitative research, initially, the number of participants was not defined and data collection was ended after identifying literal replication in each case and in the amount of the three cases (YIN, 2015). After the literal replication was verified, two or three more interviews were carried out in each municipality, confirming data saturation and determining the end of collection.

All interviews were transcribed in full and preserved to obtain paralinguistic information. Although the transcript was not returned to participants for comments and corrections, they were consulted, after the interviews, regarding the permission to use all the information collected.

Thematic content analysis was used (BARDIN, 2011), defined by the semantic criterion, according to pre-analysis, material exploration, treatment of results, inference and interpretation.

Pre-analysis aimed to make operational and systematize the initial ideas through text skimming. Exploration of material consisted of coding and categorizing the data obtained. Coding was performed by "coding operations" (BARDIN, 2011), consisting of "transcription of specific characteristics, allowing to achieve a representation of content or its expression" (BARDIN, 2011)/ in other words, the effectiveness of decisions made in pre-analysis, i.e., what represents the meanings expressed in a text skimming, in addition to precise and comprehensive reading. Categorization consisted, first, in the classification of textual elements by differentiation and, later, by grouping by means of the common characteristics or meanings of these elements (BARDIN, 2011).

In material exploration by coding, indexing and the elaboration of registration units. These indexes were determined according to each subject related to PSE and intersectoral actions, which were converged in groups that formed the category "Intersectoral actions 
between Health and Education: notes for the Health at School Program", checking the data compilation data by approximating the meanings, by data convergence or literal replication in participants' speeches. Categorization consisted of classifying and grouping the registration units by divergence or convergence of results. The last phase consisted of treatment of results, inference and interpretation (BARDIN, 2011).

Data analysis was in line with the analytical technique of cross-case analysis (YIN, 2015), which is based on this study considering three individual cases that were previously conducted with a single unit of analysis "pre-designed in the same study" (YIN, 2015), "which replicated in relation to each other" (YIN, 2015) literally due to data similarity. The conduct of crossed cases was based on meaning interpretation according to thematic content analysis (BARDIN, 2011), providing a compilation of the data of the three cases in this study.

This study was approved under Opinion 1.536.529, CAAE 54705016.5.0000.5545 and by the Institutional Review Board of the State Department of Education of Minas Gerais, being developed in accordance with Resolution 466/2012 of the Brazilian National Health Council (Conselho Nacional de Saúde).

\section{Results}

PSE implementation activities included the articulation between the two sectors with a view to preventing risks and injuries. According to research participants, notes of health promotion in the school community and health education emerge:

PSE is an extremely intelligent strategy in which education and health are believed to go together. Mainly, if you implement health promotion and education actions at schools. It is a more conducive place for you to see results when it comes to health. Parents, they become more interested, we can observe this. Students feel more open because few adolescents, even in their early teens, seek health care. At school, as they are of the same age group, we see a greater impact and greater interest when we are going to develop certain actions. (H-31 Curvelo) It is of great importance because the school does not walk alone, it needs health; boys, children need to be well not only physically, but mentally, emotionally, so everything is related, connected. (E-1 Itapecerica)

Research participants point to the need for intersectoriality in daily health and education:

Because health is not only health that has to be involved, it has to involve other sectors, and the school is an ideal place. (H-28 Seven Lagoons)

It is Health integrated into education. (E-15 Itapecerica) 
I think you can only win, you know, health is our main point; without health, we do not study, do not walk, do nothing. I think that PSE is a very valuable partnership, it has to be, yes! Health and education is everything! (E-29 Sete Lagoas)

\section{The partnership between health and education is argued and justified to prevent} risks and promote health:

I believe that partnership is to see the difficulties we have at schools and to come to prevent it. I think the most important thing would be the integration of the two departments, health and education, because health to link needs education, and education needs health, so the two sectors have a very strong connection. (E-3 Itapecerica)

We have a very good partnership with the Department of Education, because if health works without education and education without health, it doesn't work?! (H-32 Curvelo)

The city needs it (PSE), our children need it, the teachers need it. [...] May God bless, that enter the minds of managers because we need this union and that it be so direct, not only campaigns of this or that, like we see vaccination campaigns, and only put the campaigns, and where's the health? That they leave the room, the table. (E-3 Itapecerica)

\section{The importance of PSE for students emerges, including the most needy:}

A project (PSE) of this greatness at school is very important, even to wake up children. We have millions of projects that we develop in the cultural area, literature, in the Portuguese Olympics. But we have to look for more partnerships to adopt schools. (E-6 Itapecerica)

The importance is for the school and for students, especially the most needy, who do not have as much assistance, it would then be an investment by the government. (E-15 Itapecerica)

The need for more integration between health and education, not only in specific actions, but to enable more access to health:

Health and education go together, I think there should be more participation. (E-8 Itapecerica)

In reality, we do not have much openness and, thus, access to health care. What comes to us? We already had, here at school, fighting dengue, now it's the focus, it was brushing. But they do not give much openness within this health, so, the school and the institution do not have access, understand? (E-5 Itapecerica)

Participants emphasized the lack of action by FHS teams at schools in a municipality without adhering to PSE:

Currently, in this FHS team we have no connection with Education, we do not work at schools. We know it exists. (H-1 Itapecerica)

That they come to school more, that they try to find out what problems have affected our school the most with regard to health. (E-1 Itapecerica) 
We participate together, sit together, decide what we are going to do, there is not! It is complicated here, even going back to FHS, as it is divided by neighborhoods and being served in your neighborhood, they don't even serve you here. It's okay that this is democracy, it's part of it, but it doesn't justify it, if you have an emergency, they won't assist you. (E-3 Itapecerica)

I don't see that relationship. The only time I saw it was two years ago when there was an HPV vaccination campaign. Very little! The performance of health center employees with the school is weak. (E-13 Itapecerica)

It is not only here, in our FHS team, that there is a deficiency in this field, you know? There is no work that is done together with schools. (H-4 Itapecerica)

\section{However, with intersectoriality, activities take place even without adhering to PSE:}

At schools, they do a lot of campaigning, just like there was an outbreak of dengue, then, we did a dengue campaign, the dentist came to teach children how to brush their teeth; and groups for the prevention of sexually transmitted diseases and drug use. Generally, each FHS team goes to the school in the area covered. (H-3 Itapecerica)

The priority is children as the focus of action in the education and health sectors: Health personnel should go to school more, because we are working with children ... The priority is children; health and education go together. (E-8 Itapecerica)

With intersectoriality, it is possible to intervene on the determinants and act on behaviors that can be modified:

At school, you are involving health in learning, you are richer. Working on changing habits, preventing diseases, then, at school, you get children, you get adolescents, I believe that the modification of being, of acting, is better. (H-32 Curvelo)

Participants reported that management implies intersectorality:

I think that with the will of management and politics, so that we can work because, if not, there is no point in wanting to do it together, if we cannot do it, there is no resource or support. [...] it had to be an action from above, they have to make arrangements for us to work. (H-7 Itapecerica)

Things do not depend only on CHWs, on CHWs' will, even on nurses, because, like it or not, there is a hierarchy that must be followed. So, many things we want to do, but there is no material, this lack of support, organization, resources. (H-5 Itapecerica)

The need for intersectoriality is evident in order to achieve the expanded concept of health:

Great opportunity to talk about our needs, what is active and what can be improved in education and health. The two sectors go together so that children can learn better. The 
need I find would be for us to always emphasize the physical and mental health of children so that we can reach our goal, which is... what is our goal? Let children learn. So, for them to learn, it is necessary that they have a good quality of life. What does quality of life involve? Education, health, housing and food, so we depend a lot on health for students to achieve the desired learning. (E-1 Itapecerica)

Health is the main reason because we, having health, we have everything. For children, for us, health comes first! (E-10 Itapecerica)

I think that PSE is an education itself. Health is a whole, it is a physical, mental and social well-being that is linked to human beings all the time. (E-50 Curvelo)

The possibility of changing people's awareness by making their focus on prevention and promotion. I think the big role and the big change that has to happen is for people to prevent themselves and not just treat. (H-22 Curvelo)

Integration with the family emerges as an indication for the success of PSE:

OPSE would have to be developed in partnership with the family, it has to bring the family into the school because we pass it on to students and they pass it on inside the house. Family has to be together for them to understand what is happening. (E-49 Curvelo)

I believe that this partnership between education, school, family, health will continue (E-50 Curvelo).

The results of this study point to the importance of PSE, which brings health and education together, enabling the development of health actions in the school environment. However, although it has $100 \%$ adherence to PSE, the municipality of Sete Lagoas showed less proximity to the health sector, when compared to Itapecerica, without adhering to PSE, distancing itself from the proposal of this program. In Itapecerica, the actions developed at schools by health and education professionals are similar to those developed in Sete Lagoas, with a focus on preventing preventable diseases, combating dengue, oral health and sexual health (FN).

Considering the single unit of analysis "the context of integration between health and education and (non) adherence to PSE", adopted for the three cases, it is considered that the literal replication in the cases, conferred by data saturation and an analytical generalization in a multiple case study leads to understanding that integration between these sectors takes place in the scenarios studied, in the actions mentioned above, even if the municipality does or does not adhere to PSE, which can confer external generalization to realities similar to the scenarios studied. 


\section{Discussion}

Health is not done alone. To promote health and prevent risks and injuries, it is essential that other sectors act for comprehensive and intersectoral care (PERES; GRIGOLO; SCHNEIDER, 2017). Intersectoriality is an important strategy for promoting students' health (FARIAS; SÁ; FIGUEIREDO et al., 2016). It proposes an articulation of knowledge, potential and experiences of subjects and different sectors (DIAS; VIEIRA; SILVA et al., 2016).

Intersectoriality consists of developing actions that positively impact the lives of people and communities. These actions need to be planned, in an articulated and joint way, involving the knowledge and experiences of the different sectors. Intersectoral work requires sharing knowledge and actions with a view to improving the population's quality of life, achieving health promotion (PERES; GRIGOLO; SCHNEIDER, 2017).

The partnership between education and health enables the adequate development of individuals. For this, it is necessary a collective action seeking to work the actions carried out jointly (PEREIRA; SANTOS; NUNES et al., 2015). Study findings point to a partnership between these sectors. Although this partnership exists, it was considered punctual and limited, focused only on the prevention and control of risks (BRASIL; SILVA; SILVA et al., 2017). Alliances and partnerships between sectors are essential for the protection of students' well-being. Adopting fragmented initiatives has hindered the achievement of results favorable to changes in the risk behavior of students (MAATOUG; MSAKNI; ZAMMIT et al., 2015).

Intersectorial work is an important strategy to work on health promotion with students, thus forming a support network responsible for helping them understand their transformations and allowing them to develop healthily (SOARES; LEITE, 2015). However, greater integration between the health and education sectors is necessary to achieve good results. This link must go beyond simply sharing physical space and material and human resources. Joint planning is essential, assessing students' needs, appropriating and adapting actions to their needs, and training professionals (LANGFORD; BONELL; JONES et al., 2015).

The intersectoral actions between education and health, although very important, have little scope. Articulation between sectors must be included in routine and professional practice for developing more effective actions in the school 
environment (SILVA; BODSTEIN, 2016). For Maffesoli (MAFFESOLI, 2010), the way of life of each person and of the masses, the know-how, know-say and know-live defines the everyday. In daily practice, it implies coexisting in intersectoral actions and using professional know-how for effective and affective comprehensive care for health promotion and prevention of risks and injuries in the school environment.

The relationship between health and education is an important pillar of PSE. However, this relationship is often summarized in actions developed in a timely manner (FARIAS; SÁ; FIGUEIREDO et al., 2016). Intersectoral work requires simultaneous efforts to achieve results, requiring dialogue, involvement and connection of all actors involved (TOOHER; COLLINS; BRAUNACK-MAYER et al., 2017).

The school environment is an important space for actions by the FHS team; however, these actions are not carried out due to other activities developed in this service. A study carried out in Fortaleza, Ceará, Brazil, points to spontaneous demand as a factor that makes it difficult for FHS professionals to develop actions jointly with education (BRASIL; SILVA; SILVA et al., 2017). Despite this, collective construction and co-management between sectors is necessary for the development of PSE. Therefore, it is important to create strategies that strengthen ties and bring health closer to education (PRADO; MEDINA; AQUINO, 2017).

Health and education professionals need to have a different perspective on issues involving students, in order to propose policies and actions to be developed in a comprehensive manner, taking into account some of educational guidelines, how to communicate and get to know each other, carrying out actions with a view to the public's vulnerabilities. The union of these sectors can transform the reality of students, making them protagonists in the care of their health, as well as disseminators of risk prevention (ABRAMOWICZ; CRUZ; MORUZZI, 2016; PRADO; MEDINA; AQUINO, 2017).

When analyzing the school environment and the audience of children and adolescents, it can be considered that, in the context of postmodernity, it is believed that the human being lives in a tribe. In these tribes, they play, at the same time, the role of spectators and actors of the process (MAFFESOLI, 2014), being able to use their powers and be actors, main actors, to promote their health and spectator of healthier life choices. Thus, "it is necessary to bring out the treasure that is there. There is a treasure in children, in students, in others; therefore, all the work, in a way, consists not only of pulling, but of making it come out, accompanying a process" (D’ÁVILA, 
2017, p. 1410). Furthermore, student engagement in actions to promote healthy habits is an essential tool for the group/tribe of students to incorporate the adoption of new behaviors (HOELSCHER; MOAG-STAHLBERG; ELLIS et al., 2016).

With intersectorality, PSE activities are possible and it is possible to intervene on the conditions and act on behaviors that can be modified. For greater reach of actions, activities carried out in the school environment must be adapted to the skills of each audience, enabling greater enthusiasm and interest in the actions performed (NORMAN; NYBERG; ELINDER et al., 2016). District managers have a significant influence on the interorganization of intersectoral actions (DIAS; VIEIRA; SILVA et al., 2016). For the sustainability of PSE as a policy, managers must direct efforts towards the development of actions that influence the population's quality of life and coordinate intersectoral actions through the strengthening of territorialization strategies and co-responsibility for health and education (FARIAS; SÁ; FIGUEIREDO et al., 2016). Furthermore, it is up to the managers to make the planned actions feasible, with financing, considering the articulation with the spheres of power and with other sectors (LANGFORD; BONELL; JONES et al., 2015).

Intersectoriality in health involves constant negotiations to determine the actions to be developed. Although complex, it is a fundamental tool for the convergence of initiatives, transforming the fragmented model of health care (MAGALHÂES, 2015). The practice of empowering the school community, through intersectoral actions, brings a new meaning to health, which is no longer seen as something only biological (SILVA; BODSTEIN, 2016) and includes comprehensive care and co-responsibility for health promotion. The expanded concept of health itself becomes an incentive for intersectoral actions, as it is understood that health is beyond the sector itself and, for it to be achieved, it needs the performance of other services, such as schools. Finally, intersectorality refers to the expansion of health and comprehensive care and can overturn the fragmented and mechanistic model of health actions. This implies adopting a new way of working, uniting with other sectors to face the problems (PERES; GRIGOLO; SCHNEIDER, 2017; VIEGAS; PENNA, 2015).

In this way, the medical culture, of biologicist reason, can be replaced by comprehensive and person-centered care (VIEGAS; PENNA, 2015); in the human being who, in contemporary times, turns to the culture of feeling (MAFFESOLI, 1995), of being together, causing a resurgence of group ties, 
the desire to belong to a group, to be part of communities (MAFFESOLI, 2010; MAFFESOLI, 2014; MAFFESOLI, 2005), in life expectancy with better quality (VIEGAS; PENNA, 2015).

Health alone will not be able to improve students' quality of life. To achieve this goal, it is necessary to involve other sectors of the community and family members (SOUSA; ESPERIDIÃO; MEDINA, 2017). The family and society play an important role in the education of children and adolescents, as well as the school. After the family environment, the school becomes one of the main promoters of socialization of individuals, corroborating the consent of differences and disseminating equality and respect to all citizens (OLIVEIRA; ALBERTO; BITTENCOURT, 2016). The information and values taught by these entities imply the formation of being, enable better choices, help clarify doubts and even strengthen students in situations of vulnerability (SILVA; NUNES; PRIOTTO et al., 2015).

To understand the social and family context, it is necessary to strengthen ties with the family, and it is necessary to establish moments of dialogue with parents (COSTA; ZEITOUNE; QUEIROZ et al., 2015). Still, it is of utmost importance to reserve moments to listen to the problems present in the community responsible for directly affecting students' quality of life (NUNES; OLIVEIRA; BEZERRA et al., 2014). These partnerships help to restore the health of children/adolescents and transform their customs.

Human living is uneven, irregular and distinct. To understand it in broadly and comprehensively, it is necessary to be aware of the different realities where it is inserted (MAFFESOLI, 2014), which was configured in this study with three cases. Joint work of parents, teachers and health professionals enables the solution of problems raised in the school environment (LÓPEZ; FIERRO; MONTOYA; ORTEGA, 2016). Adequate preparation of parents contributes to the adoption of healthy habits by children, since it can be configured as sharing of healthier acts and attitudes in the family environment (NORMAN; NYBERG; ELINDER et al., 2016). Family involvement also makes it possible to recognize students' risk behaviors because they replicate behaviors experienced at home at school (MONTEIRO; BIZZO, 2015).

Even with the approach of health professionals to the inequalities that emerge in the service, policies covering other departments and establishing intersectoriality as an important strategy for the promotion of students' health are also necessary (FARIAS; SÁ; FIGUEIREDO et al., 2016; MORRISON; PONS-VIGUÉS; DIEZ 
et al., 2015). Moreover, it is also necessary to involve the community and recognize its capacity to promote self-care, valuing its remarkable role in the elaboration of strategies to face its problems (NUNES; OLIVEIRA; BEZERRA et al., 2014).

The union of education and health sectors is a necessary pillar to be able to transform the country's health conditions. However, this will only be achieved if the actions developed are planned and executed involving all actors: students, parents, community, managers, health and education professionals.

\section{Conclusion}

The results clarify that intersectoriality is an important strategy for health promotion and the prevention of risks and injuries of students. However, full involvement of health and education is necessary, from elaboration to execution of actions, with the involvement of the family and the community being considered. These services need to work in an articulated way, valuing different knowledge, with a view to improving students' quality of life.

Health and education indicate intersectoriality, but it proves to be fragile, permeated by the practice of fragmented, punctual and limited actions, implying a low improvement in the health conditions of those involved.

As it is an intersectoral program, designed to be developed jointly, PSE can enable a closer relationship between these services by expanding access to health promotion and risk prevention actions for the school community, acting on the determinants and conditions of the health-disease process. Municipal managers have a fundamental role in making this program feasible and carrying out actions with the responsibility of the sectors. Nurses have an important role in articulating intersectoral actions. The empowerment of students, through intersectoral actions, enables them to be protagonists of self-care, which may imply daily actions that thus transform their reality and have a better quality of life. Comprehensive health and education imply intersectorality and organized civil society.

\section{References}

ABRAMOWICZ A.; CRUZ A. C. J.; MORUZZI A. B. Some notes: Who cares about the common national curriculum for early childhood education? Debates em educaçáo, v. 8, n. 16, p. 46-65, 2016. Availablefrom:<http://www.seer.ufal.br/index.php/debateseducacao/article/ viewFile/2385/2134>. Cited 2017 May 11. 
BARDIN L. Análise de conteúdo. 1. ed. Reto L. A.; Pinheiro A., tradutor. São Paulo (SP): Edições 70, 2011.

BIGS, Brazilian Institute of Geography and Statistics. Estimated population 2016.Available from: <http://cidades.ibge.gov.br/xtras/uf.php?lang=\&coduf=31\&search=minas-gerais $>$.

BRASIL E. G. M.; SILVA R. M. S.; SILVA M. R. F.; RODRIGUES D. P.; QUEIROZ M. V. O. Adolescent health promotion and the School Health Program: complexity in the articulation of health and education. Rev Esc Enferm USP, v.51, 2017. Available from: <http://www.revenf.bvs.br/scielo.php?script=sci_arttext\&pid=S0080-62342017000100454> Cited: 2019 March 06.

BRASIL. Ministério da Saúde. Caderno de atenção básica: saúde na escola, Brasília, DF, Ministério da Saúde: Secretaria de Atenção à Saúde, Departamento de Atenção Básica, 2009. Disponível em: <http://dab.saude.gov.br/docs/publicacoes/cadernos_ab/ab cad24.pdf>.

BRASIL. Ministério da Saúde. Decreto-lei no 6.286, de 5 de dezembro de 2007. Institui o Programa Saúde na Escola-PSE e dá outras providências, Brasília, DF, 2007. Disponível em: <http://www.planalto.gov.br/ccivil_03/_ato2007-2010/2007/decreto/d62 86.htm>.

CHIARI A. P. G.; FERREIRA R. C.; AKERMAN M.; AMARAL J. H. L.; MACHADO K. M.; SENNA M. I.B. Inter-sector network in Brazil's School Health Program: subjects, perceptions, and practices. Cad Saúde Pública, v. 34, n. 5, 2018. Available from: <http:// www.scielo.br/scielo.php?script=sci_arttext\&pid=S0102-311X2018000505009> Cited: 2019 Mach 06.

COSTA R. F.; ZEITOUNE R. C. G.;QUEIROZ M. V. O.;GARCÍA C. I. G.; GARCÍA M. J. R. Adolescent support networks in a health care context: the interface between health, family and education. Rev. esc. enferm. USP, v. 49, n. 5, 2015. Available from: <http://www.scielo.br/ scielo.php?script=sci_arttext\&pid=S0080-62342015000500741>. Cited 2019 March 06.

D'ÁVILA C. Educação como processo de iniciação: por uma didática raciovitalista no contexto da pós-modernidade - entrevista com o sociólogo Michel Maffesoli. Rev. Diálogo Educ., Curitiba, v. 17, n. 54, p. 1401-1417, jul./set. 2017. Available from: http://dx.doi.org/10.7213/1981416X.17.054.EN01

DIAS M. S. A.; VIEIRA F. M. B. R.; SILVA L. C. C.; VASCONCELOS M. I. O.; MACHADO M. F. A. S. Inter-professional collaboration in the 'Health and Prevention in Schools' Project. Ciênc saúde colet, Brazil, v. 21, n. 6, p. 1789-1798, 2016. Available from: <http://www.scielo.br/ pdf/csc/v21n6/en_1413-8123-csc-21-06-1789.pdf> Cited in: 2018 Feb 25.

FARIAS I. C. V.; SÁ R. M. P. F.; FIGUEIREDO N.; FILHO A. M. Cross-sectorial Analysis in the Health at Schools Program. Rev bras educ medica, v. 40, .2, p. 261-7, 2016. Available from: <http://www.scielo.br/pdf/rbem/v40n2/1981-5271-rbem-40-2-0261.pdf>. Cited: 2017 Mar 12. 
GONDIM P. S.; SOUTO N. F.; MOREIRA C. B.; CRUZ M. E. C.; CAETANO F. H. P.; MONTESUMA F. G. Accessibility of adolescents to sources of information on sexual and reproductive health. Ver bras crescimento desenvolv hum, Brazil, v. 25, n. 1, p. 50-3, 2015. Available from: <https://www.revistas.usp.br/jhgd/article/view/96767/96166>Cited: 2017 Apr 25. HOELSCHER D.M.; MOAG-STAHLBERG A.; ELLIS K.; VANDEWATER E. A.; MALKANI R. Evaluation of a student participatory, low-intensity program to improve school wellness environment and students' eating and activity behaviors. Int J Behav Nutr Phys Act, v. 13, n. 59, 2016. Available from: <https://www.ncbi.nlm.nih.gov/pmc/articles/PMC4866070/>. Cited 2017 Apr 22.

LANGFORD R.; BONELL C.; JONES H.; CAMPBELL R. Obesity prevention and the Health promoting Schools framework: essential components and barriers to success. Int J Behav Nutr Phys Act, v. 12, n. 15, 2015. Available from: <https://www.ncbi.nlm.nih.gov/pmc/articles/ PMC4330926/>. Cited 2018 Feb 25.

LÓPEZ M. M.; FIERRO E. F.; MONTOYA M. S. F.; ORTEGA A. M. A. Education and promotion of healthy food habits in preschoolers. An educational experience. Rev iberoam educ investi Enferm, v. 6, n. 2, p. 47-53, 2016. Available from: <http://www.enfermeria21.com/ revistas/aladefe/articulo/202/> Cited: 2017 Apr 22.

MAATOUG J.; MSAKNI Z.; ZAMMIT N.; BHIRI S.; HARRABI I.; BOUGHAMMOURA L.; et al. School-Based Intervention as a Component of a Comprehensive Community Program for Overweight and Obesity Prevention, Sousse, Tunisia, 2009-2014. Prev Chronic Dis, v. 12, 2015. Available from: <https://www.ncbi.nlm.nih.gov/pmc/articles/PMC4584471/?tool=pubmed>. Cited: 2018 Feb 25.

MAFFESOLI M. A contemplação do mundo. 1. ed. Porto Alegre (RS): Artes e Ofícios, 1995.

(RJ): Vozes, 2005.

. Elogio da razão sensível. 2. ed. Stuckenbruck ACM, tradutor. Petrópolis . O conhecimento comum: introdução à sociologia compreensiva. 2. ed. Trinta A. R., tradutor. Porto Alegre (RS): Sulina, 2010.

. The time of the tribes: the decline of individualism in mass societies. 5. ed. Rio de Janeiro (RJ): Forense Universitária, 2014.

MAGALHÃES R. Constraints and opportunities for inter-sector health promotion initiatives: a case study. Cad saude publica, v. 31, n. 7, p. 1427-36, 2015. Available from: <http://www. scielo.br/pdf/csp/v31n7/0102-311X-csp-31-7-1427.pdf>. Cited 2017 Mar 12.

MONTEIRO P. H. N.; BIZZO N. Health in school: an examination of the reference documents for the forty years of compulsory health programs, 1971-2011. História, Ciências, Saúde Manguinhos, v. 22, n. 2, p. 411-27, 2015. Available from: <http://www.scielo.br/pdf/ hcsm/v22n2/0104-5970-hcsm-2014005000028.pdf>Cited: 2018 Feb 23. 
MORRISON J.; PONS-VIGUÉS M.; DIEZ E.; PASANIN M. I.; SALAS-NICÁS S.; BORRELL C. Perceptions and beliefs of public policymakers in a Southern European city. Int J Equity Health, v. 14, n. 18, 2015. Available from: <https://www.ncbi.nlm.nih.gov/pmc/ articles/PMC4343064/>. Cited 2017 May 11.

NITSCHKE R. G.; THOLL A. D.; POTRICH T.; SILVA K. M.; MICHELIN S. R.; LAUREANO D. D. Contributions of Michel Maffesoli's Thinking to Research in Nursing and Health. Texto contexto enferm, v. 26, n. 4, p: 1-12, 2017. Available from: <http://www.scielo.br/ pdf/tce/v26n4/en_0104-0707-tce-26-04-e3230017.pdf>. Cited 2018 March 18.

NORMAN A.; NYBERG G.; ELINDER L. S.; BERLIN A. One size does not fit allqualitative process evaluation of the Healthy School Start parental support programme to prevent overweight and obesity among children in disadvantaged areas in Sweden. BMC Public Health, v. 16, n. 37, 2016. Available from: <https://www.ncbi.nlm.nih.gov/pmc/articles/ PMC4712479/>. Cited 2017 Apr 22.

NUNES J. M.; OLIVEIRA E. N.; BEZERRA S. M. N.; COSTA P. N. P.; VIEIRA N. F. C. Educational practice with women in the community: prevention of pregnancy in adolescence. Texto Contexto Enferm, v. 23, n. 3, p. 791-8, 2014. Available from: <http://www.scielo.br/pdf/ tce/v23n3/0104-0707-tce-23-03-00791.pdf>. Cited 2017 Sep 17.

OLIVEIRA C.E.; ALBERTO M. F. P.; BITTENCOURT N. F. B. Tensions and contradictions in political discourses on the fight against homophobia in the context of the Brazilian school. Rev latinoam cienc soc niñez juv, v. 14, n. 2, p. 1479-92, 2016. Available from: http://www. scielo.org.co/pdf/rlcs/v14n2/v14n2a41.pdf>. Cited 2017 May 11.

PEREIRA S.; SANTOS J. N.; NUNES M. A.; OLIVEIRA M. G.; SANTOS T. S.; REIS V. O. M. Health and education: a partnership required for school success. CoDAS, v. 27, n. 1, p.58-64, 2015. Available from: <http://www.scielo.br/scielo.php?script=sci_arttext\&pid =S2317-17822015000100058> Cited: 2017 Mar 12 .

PERES G. M.; GRIGOLO T. M.; SCHNEIDER D. R. Challenges of the Intersectoral Approach in the Implementation of a Program for the Prevention of Drug Abuse. Psicologia: Ciência e Profissão, v. 37, n. 4, p. 869-882, 2017. Available from: <http://www.scielo.br/pdf/ pcp/v37n4/1414-9893-pcp-37-04-0869.pdf>. Cited: 2019 March 06.

PRADO N. M. B. L.; MEDINA M. G.; AQUINO R. Intersectoral action for health promotion in local systems: a study of evaluability. Saúde debate, v. 41, n. 3, 2017. Available from: <http://www. scielo.br/scielo.php?script=sci_arttext\&pid=S0103-11042017000700214>. Cited 2019 March 06.

RIBEIRO M. S. S; RIBEIRO C. V. Health and prevention at schools: elements for evaluating social projects in Juazeiro, Bahia, Brazil. Interface (Botucatu), Brazil, v. 19, n. 53, p. 337-48, 2015. Available from: <http://www.scielo.br/pdf/icse/2015nahead/1807-5762icse-1807-576220140474.pdf> Cited: 2017 Apr 23. 
SILVA C. S.; BODSTEIN R. C. A. A theoretical framework on intersectoral practice in School Health Promotion. Cien saude colet, v. 21, n. 6, p. 1777-88, 2016. Available from:<http:// www.scielo.br/scielo.php?pid=S1413-81232016000601777\&script=sci_arttext\&tlng=en $>$. Cited 2017 Mar 12.

SILVA M. A. L.; NUNES M. R.; PRIOTTO E. M. T. P.; BRAGA I. F.; SANTOS S. D. Protective factors to reduce vulnerability to health. Rev min Enferm, v.19, n. 3, p. 653-58, 2015. Available from: <http://www.reme.org.br/artigo/detalhes/1030>. Cited 2017 Mar 19.

SOARES T. M. S.; LEITE M. C. L.; MEINCKE S. M. K.; RIBEIRO J. P.; GOMES G. C.; SILVA P. A. Sex education for teens: alliance between school and nursing/ healthcare. Revista espaço para a saúde, v. 16, n. 3, p. 47-52, 2015. Available from: <http://www.uel.br/revistas/uel/ index.php/espacoparasaude/article/view/20019>Cited: 2017 Mar 19.

SOUSA M. C.; ESPERIDIÃO M. A.; MEDINA M. G. Intersectorality in the 'Health in Schools' Program: an evaluation of the political-management process and working practices. Ciência saúde coletiva, Brazil, v. 22, n. 6, p. 1781-90, 2017. Available from: <http://www.scielo. br/pdf/csc/v22n6/en_1413-8123-csc-22-06-1781.pdf>Cited: 2018 Feb 23.

TOOHER R.; COLLINS J.; BRAUNACK-MAYER A.; BURGESS T.; SKINNER R.; O'KEEFE M.; et al. Intersectoral collaboration to implement school-based health programmes: Australian perspectives. Health Promotion International, v. 32, n. 2, p. 312-321, 2017. Available from: <https://academic.oup.com/heapro/article/32/2/312/3062464>. Cited 2019 March 06.

VIEGAS S. M. F.; PENNA C. M. M. Integrality: life principle and right to health. Invest educ Enferm, v. 33, n. 2, p. 237-247, 2015. Available from <http://www.scielo.org.co/scielo. php?script=sci_arttext \&pid=S0120-53072015000200006\&lng=en\&nrm=iso $>$. Cited 2018 Mar 04.

VIEGAS S. M. F.; PENNA C. M. M. The dimensions of the comprehensiveness on healthcare within the routine of the Family Health Strategy in the Jequitinhonha Valley, Minas Gerais, Brazil. Interface (Botucatu), Brazil, v. 19, n. 55, p. 1089-1100, 2015. Available from: <http:// www.scielo.br/pdf/icse/v19n55/1807-5762-icse-1807-576220140275.pdf> Cited: 2017 Apr 25.

YIN R. K. Case study: planning and methods. 5. ed. Herrera C. M., translator. Porto Alegre (RS): Bookman, 2015. 


\section{Resumo}

\section{Açóes intersetoriais entre a saúde e a educação: apontamentos para o programa saúde na escola}

Objetivo: compreender as açóes intersetoriais entre a Saúde e a Educação e o contexto do Programa Saúde na Escola em três municípios de distintas regiōes sanitárias do estado de Minas Gerais, Brasil. Método: trata-se de um estudo de casos múltiplos holístico-qualitativo, fundamentado na Sociologia Compreensiva do Cotidiano, com 91 participantes, sendo 38 profissionais da Saúde e 53 profissionais da Educação. Utilizaram-se a entrevista individual aberta e os registros em notas de campo operacionais do desenvolvimento da pesquisa. Os dados foram coletados em 2016 e utilizou-se a Análise de Conteúdo Temática, obedecendo à técnica analítica da síntese cruzada dos casos, em consonância ao referencial metodológico de estudo de casos múltiplos holístico. Resultados: apontam um baixo envolvimento entre os setores Saúde e Educação levando à prática de açôes fragmentadas, pontuais e limitadas e implicando baixa melhoria das condições de saúde. Conclusóes: para modificar esse contexto, é fundamental o envolvimento dos profissionais da Saúde e da Educação, além dos próprios escolares, pais, comunidade e gestores. A união desses atores é necessária para a transformação das condiçóes de saúde dos estudantes. No entanto, isso só será alcançado se as açóes desenvolvidas forem planejadas e executadas envolvendo esses atores e a comunidade escolar.

> Palavras-chave: colaboração intersetorial; saúde; educação; saúde escolar; promoção da saúde. 


\section{ERRATUM}

In the article "Intersectoral actions between health and education: notes on the Health at School Program", with DOI number: http://dx.doi.org/10.1590/S010373312021310224 published in the journal Physis: Revista de Saúde Coletiva, v. 31, n. 2, e310224, on page 1, author name error:

\section{WHERE IT READS:}

Ilana Moutian

\section{READ:}

Paula Luciana Gonçalves Pereira 